\title{
MODELING OF PLASTIC DEFORMATION OF POROUS POWDER MATERIALS
}

\author{
G. ZAYATS, R. KUSIN and V. KAPCEVICH
}

Institute of Mathematics of National Academy of Sciences of Belarus

Surganov 11, 220072, Minsk, Belarus

E-mail: zayats@im.bas-net.by

Institute of Powder Metallurgy of Belarus

Platonov 41, 220071, Minsk, Belarus

E-mail: nil23niipm@newmail.ru

Belarusian Agrarian Technical University

Skorini 99, 220023, Minsk, Belarus

Received September 09, 2003; revised November 19, 2003

\begin{abstract}
In the present study the model of plastic deformation of porous powder materials (PPM) is described and numerically simulated. This model enables prediction of change of fundamental technological parameters of PPM in plastic deformation conditions, i.e. porosity, pore size, specific surface and mechanical properties. Porous media is described by unit cells consisting of eight powder particles. The parameters of unit cell (the distance between the centers of particles, the angles of the array and the dimensions of interparticle connections) form the model of porous material and define its technological characteristics. The model takes into account the effect of deforming anisotropy on PPM properties. Calculations are performed in nonorthogonal coordinates connected with unit cell. In the case of uniaxial straining obtained numerical results have shown good agreement with the experimental results.
\end{abstract}

Key words: mathematical simulation, porous powder materials, plastic deformation.

\section{INTRODUCTION}

The development of science and engineering highlights the problem of creation of new technologies which produce porous materials with improved performance. A number of technologies for making porous materials are based 
on using plastic deformations. In this process prognosis of performance by mathematical modelling is an important aspect which leads to economy of the resources during technological experiments. The early investigation of the mechanical behavior of granular materials was carried out by Coulomb [2]. Drucker and Prager [4] and Shield [10] have applied the theory of elasticplastic solid for describing the mechanics of granular materials. There are a number of the studies [6;9] in which phenomenological approach are used, but in these investigations the main structural parameters of the porous material: the dimensions of the particles, the angles of the array of particles, the dimensions of the interparticle contacts, etc., are not considered. The discrete-contact theories which are based on the dependence of the process of plastic deformation on the structural parameters of the porous material, are developed in the papers $[3 ; 5 ; 7 ; 13 ; 14]$.

The present report is devoted to mathematical investigation of the processes of plastic deformation of porous powder materials and to the definition of change of their fundamental technological parameters.

The generalized discrete-contact model of PPM which describes the interrelation between their structure and physic-mechanical parameters of the stressed-strain state in the process of pressing is suggested. The structure of a porous body is represented as a certain regular array of powder particles of spherical shape. The object of mathematical investigation is an elementary cell. It represents a parallelepiped made by eight powder particles contacting with one another (Fig. 1). At each point of the elementary cell, the laws of the classical mechanics are satisfied. The parameters of the elementary cell

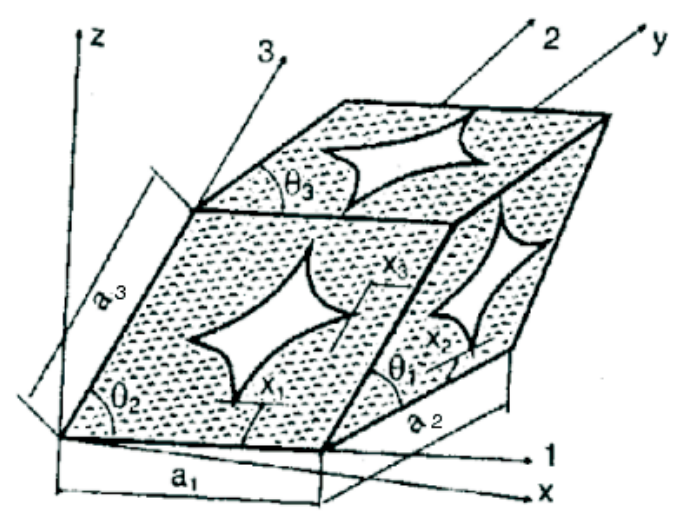

Figure 1. The model of the elementary cell.

correspond to the basic parameters of the PPM structure: the dimensions of the sides $a_{i}(i=1,2,3)$ correspond to the distances between the centers of the 
particles, the corners in the sides $\Theta_{i}(i=1,2,3)$, to the angles of the array of particles, the dimensions of the interparticle contacts $x_{i}(i=1,2,3)$, to the dimensions of contact necks.

Using the parameters of the model, it is possible to calculate structural properties of PPM such as porosity, specific surface and the size of pores [15].

The geometric calculations yield the following expression for the porosity

$$
\begin{aligned}
P & :=1-\frac{V_{p}}{V_{0}} \\
& =1-\frac{\alpha_{V} \pi D^{3}}{6 a_{1} a_{2} a_{3}\left(1-\sum_{i=1}^{3} \cos ^{2} \Theta_{i}+2 \cos \Theta_{1} \cos \Theta_{2} \cos \Theta_{3}\right)^{1 / 2}},
\end{aligned}
$$

for the specific surface

$$
S_{V}=\frac{6(1-P)}{\alpha_{V} D}\left[\alpha_{S}-\left(2 \sum_{i=1}^{3} S_{c t i}\right) / \pi D^{2}\right]
$$

and for the sizes of pores

$$
d_{p i}=\frac{\left(a_{j}^{2}+a_{k}^{2}-2 a_{j} a_{k} \cos \Theta_{i}\right)^{1 / 2}}{\sin \Theta_{i}}-\tilde{D}_{i}
$$

where $V_{0}$ is the volume of the elementary cell, $V_{p}$ is the volume of the powder particles in the elementary cell, $\alpha_{V}$ and $\alpha_{S}$ are the volumetric and surface factors of the shape, $D$ is the diameter of a powder particle and $\tilde{D}_{i}=2\left(\frac{S_{M i}}{\alpha_{V} \pi}\right)^{1 / 2}$ is the effective diameter of a powder particle, where $S_{c t i}(i=1,2,3)$ is the area of the contact lying in the direction of the $i$-th axis, $S_{M i}(i=1,2,3)$ is the area of the powder material on the $i$-th side of the elementary cell.

\section{MATHEMATICAL MODEL}

The investigations are done in a nonorthogonal coordinate system $(1,2,3)$ connected with the elementary cell (Fig. 1). The orientation of this coordinate system relative to the main axes of the stress tensor is defined by the generalized Lame coefficients which determine all the geometric properties of the nonorthogonal coordinate system and are to be found from the relation

$$
h_{i \alpha}=\left(\vec{e}_{i} \cdot \vec{e}_{\alpha}\right),
$$

where $\vec{e}_{i}(i=1,2,3)$ and $\vec{e}_{\alpha}(\alpha=x, y, z)$ are the basic vectors of the nonorthogonal coordinate system and of the external Cartesian coordinate system, respectively. 
Using the theory of tensor calculus [1], for the nonorthogonal coordinate system we can write a metric tensor

$$
g_{i j}=\sum_{\alpha} h_{i \alpha} h_{j \alpha}
$$

A contravariant metric tensor $g^{i m}$ is defined from the equation

$$
\sum_{m} g^{i m} g_{m j}=\delta_{j}^{i}
$$

where $\delta_{j}^{k}$ is the Kronecker delta.

In turn, the components of the local stress tensor $\sigma^{i j}$ in the nonorthogonal coordinate system are expressed in terms of the values of the main components and Lame coefficients

$$
\sigma^{i j}=\sum_{\alpha} h_{\alpha}^{i} h_{\alpha}^{j} \sigma_{\alpha}
$$

here $h_{\alpha}^{i}=\sum_{m} g^{i m} h_{m \alpha}$ represent differential parameters of 1-st order.

The model is based on the assumption (used in the majority of the discretecontact theories of the plasticity of porous materials) that the process of plastic deformation of PPM is almost completely localized in the zone of interparticle contacts $[6 ; 11 ; 12]$. The laws of plastic deformation of material are governed by the form of the plasticity function of this material. To find the condition of plasticity, we shall analyze the stressed-strain state of the powder material in the regions of the interparticle contacts of the elementary cell.

Let us consider the section of the elementary cell divided by the planes drawn in parallel with $j$-th coordinate plane of the nonorthogonal coordinate system and passing through the center of the contact located in the direction of the $k$ axis. For example, in the direction of axis 1 these sections have the form, which is presented in Fig. 2. Their areas are equal to

$$
S_{j}^{k}=S_{c t j} \delta_{j}^{k}+\left(1-\delta_{j}^{k}\right) S_{M j}(k, j=1,2,3) .
$$

In order to calculate the local stress tensor in the regions of the interparticle contact, we will write the equations of the balance of forces in the indicated sections.

The condition of the transition of the powder material in the regions of interparticle contact to the state of plastic deformation is determined on the basis of Mises's plasticity criterion. According to this criterion, the intensity of the local stresses in the region of the $k$-th contact is equal to

$$
J_{k}=\frac{1}{6}\left[3 \sum_{i, j, m, n}\left(\bar{\sigma}_{k}^{i m} \bar{\sigma}_{k}^{j n} g_{m j} g_{n i}\right)-\left(\sum_{i, m} \bar{\sigma}_{k}^{i m} g_{i m}\right)^{2}\right]=\tau_{T}^{2}
$$




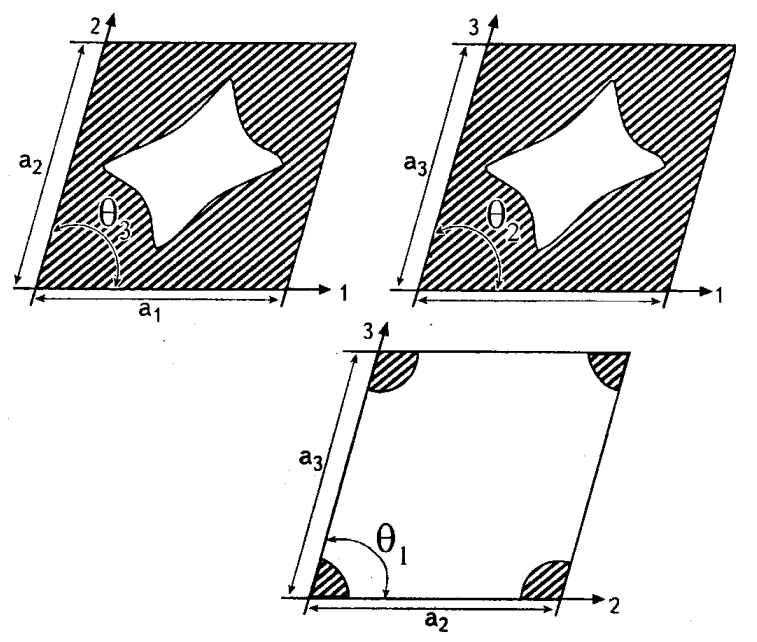

Figure 2. The sections of the elementary cell passing through the center of the contact located in the direction of the $k=1$ axis .

where $\bar{\sigma}_{k}^{i j}$ represents the local value of the stress tensor averaged over the region of the $k$-th contact, $\tau_{T}$ is the powder material yield limit. Taking into account the fact that the localization of deformations is in the interparticle contacts, the total energy of shear plastic deformations in the elementary cell is determined by the sum (over all the contacts) of the intensities:

$$
\bar{J}=\sum_{k} J_{k}=3 \tau_{T}^{2} .
$$

Having substituted the values of the components of the local stress tensor in the regions of interparticle contacts into the latter equality, we obtain the plasticity condition expressed in terms of the components of the stress tensor in the main axes

$$
\sum_{\alpha, \beta} A_{\alpha \beta} \sigma_{\alpha} \sigma_{\beta}=\tau_{T}^{2},
$$

where

$$
\begin{gathered}
A_{\alpha \beta}=\frac{1}{18} \sum_{i, j} R^{i j} h_{j \alpha} h_{i \beta}\left(3 h_{\alpha}^{i} h_{\beta}^{j}-h_{\alpha}^{j} h_{\beta}^{i}\right) \\
R^{i j}=\frac{V_{0}^{2} \sqrt{g^{i i} g^{j j}}}{a_{i} a_{j}}\left[\left(\frac{1}{S_{c t i}}-\frac{1}{S_{M i}}\right)^{2} \delta_{i}^{j}-\frac{1}{S_{M i} S_{c t j}}-\frac{1}{S_{M j} S_{c t i}}-\frac{1}{S_{M i} S_{M j}}\right] .
\end{gathered}
$$


Using the theory of plasticity and assuming that the function of plasticity is the plastic potential [8], we shall represent the components of the strain tensor in the main axes in the following form:

$$
d \varepsilon_{\alpha}=2 d \lambda \sum_{\beta} A_{\alpha \beta} \sigma_{\beta}
$$

where $d \lambda$ is an indefinite multiplier eliminated in calculations.

The changes in the geometric parameters of the elementary cell are determined by the magnitude of deformation. In this case, it is convenient to use a new nonorthogonal coordinate system connected with the deformed cell. By means of simple transformations we obtain the Lame coefficients for the new nonorthogonal coordinate system after deformation in the form

$$
h_{i \alpha}^{\prime}=\frac{h_{i \alpha}\left(1+d \varepsilon_{\alpha}\right)}{\left(\sum_{\alpha}\left(h_{i \alpha}\right)^{2}\left(1+d \varepsilon_{\alpha}\right)^{2}\right)^{1 / 2}} .
$$

The dimensions of the sides of the elementary cell after deformation are

$$
a_{i}^{\prime}=a_{i}\left(\sum_{\alpha}\left(h_{i \alpha}\right)^{2}\left(1+d \varepsilon_{\alpha}\right)^{2}\right)^{1 / 2}, \quad(i=1,2,3) .
$$

The angles of the array take on the values

$$
\Theta_{i}^{\prime}=\arccos \left\{\frac{\sum_{\alpha} h_{j \alpha} h_{k \alpha}\left(1+d \varepsilon_{\alpha}\right)^{2}}{\left[\sum_{\alpha} h_{j \alpha}^{2}\left(1+d \varepsilon_{\alpha}\right)^{2} \sum_{\beta} h_{k \beta}\left(1+d \varepsilon_{\beta}\right)^{2}\right]^{1 / 2}}\right\}
$$

and the subscripts $(i, j, k)$ take on the values $(1,2,3),(2,3,1),(3,1,2)$.

We assume that during plastic deformation the powder material is incompressible and the particles are strained without destructions and ruptures. According to the definition of the increment of deformations, we obtain the law governing the change in the powder material areas on the sides of the elementary cell [15]

$$
\frac{d S_{M j}}{S_{M j}}=\frac{V_{0} \sqrt{g^{j j}}}{\left(S_{M j}\right)^{2}} \frac{\partial S_{M j}}{\partial x_{j}} \sum_{\alpha} h_{\alpha}^{j} h_{j \alpha} d \varepsilon_{\alpha}(j=1,2,3) .
$$

The values of the derivative $\frac{\partial S_{M j}}{\partial x_{j}}$ will be determined approximately. Let us assume that the surface of a powder particle is described by the smooth enough function $S_{p}=S_{p}(z)$. Let $S_{p}(z)=S_{c t}+b z+c z^{2}$, where $S_{c t}$ is the area of the section of the interparticle contact. Let us determine the coefficients $b$ and $c$ from the conditions:

$$
\left.S_{p}\right|_{z=a / 2}=S_{1}
$$


where $S_{1}$ is the area of the maximal section of the powder particle

$$
\int_{0}^{a / 2} S_{p}(z) d z=0.5 V_{p}
$$

Using these conditions we obtain $b$ and $c$

$$
b=\frac{4\left[3 V_{p}-a\left(S_{1}+2 S_{c t}\right)\right]}{a^{2}}, c=\frac{-12\left[2 V_{p}-a\left(S_{1}+S_{c t}\right)\right]}{a^{3}} .
$$

To find the values of $\frac{\partial S_{M j}}{\partial x_{j}}$ we shall consider various ways of isolation of an elementary cell (see Fig. 3).

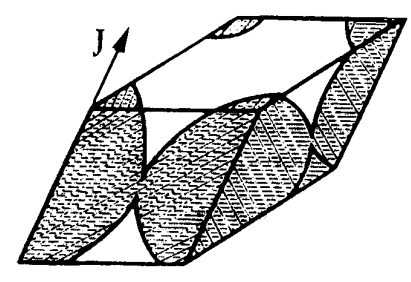

a)

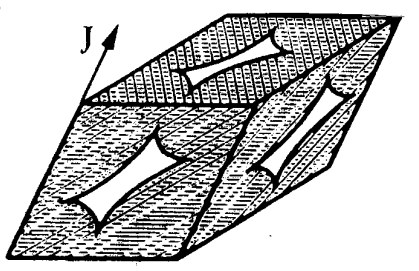

b)

Figure 3. Schemes of the elementary cell containing on its surface a) interparticle contacts and b) maximum sections of a powder particle.

Let interparticle contacts be present on its surface. Then the value of $\frac{\partial S_{M_{j}}}{\partial x_{j}}$ corresponds to $\left.\frac{\partial S_{p}(z)}{\partial z}\right|_{z=0}$. Equation (2.6) is the following

$$
\frac{d S_{c t j}}{S_{c t j}}=-4 \frac{V_{0} \sqrt{g^{j j}}}{\left(S_{c t j}\right)^{2} a_{j}^{2}}\left[3 V_{p}-a_{j}\left(S_{1 j}+2 S_{c t j}\right)\right] \sum_{\alpha} h_{\alpha}^{j} h_{j \alpha} d \varepsilon_{\alpha}, j=1,2,3 . \quad \text { (2.7) }
$$

Similarly, for the case where there are maximum sections of a powder particle on the side of the cell, the value $\frac{\partial S_{M j}}{\partial x_{j}}$ corresponds to $\left.\frac{\partial S_{p}(z)}{\partial z}\right|_{z=a / 2}$ and equation (2.6) is the following

$$
\frac{d S_{1 j}}{S_{1 j}}=-4 \frac{V_{0} \sqrt{g^{j j}}}{\left(S_{1 j}\right)^{2} a_{j}^{2}}\left[3 V_{p}-a_{j}\left(S_{1 j}+2 S_{c t j}\right)\right] \sum_{\alpha} h_{\alpha}^{j} h_{j \alpha} d \varepsilon_{\alpha}, j=1,2,3 .
$$

Thus, the system of equations (1.1)-(1.3), (2.1)-(2.8) allows one to determine the laws governing the transition of PPM to a plastic deformation state and to calculate changes in their basic properties on deformation. 


\section{NUMERICAL EXPERIMENTS AND CONCLUSIONS}

For numerical investigation, not limiting the generality, we consider uniaxial compression. In this case, the lateral surfaces of the samples are not loaded, which ensures a stressed state in which only the component $\sigma_{z}$ of the stress tensor differs from zero (provided there is no friction on the loaded surface). In this case, the condition of plasticity (2.1) takes on the following form:

$$
A_{z z} \sigma_{z}^{2}=\tau_{z}^{2}
$$

The law of flow associated with the function of plasticity (2.2) is

$$
d \varepsilon_{\alpha}=d \varepsilon_{z} \frac{A_{\alpha z}}{A_{z z}}
$$

Using the model, the calculations were carried out for samples of bronze powder with the initial porosity $P=39 \%$.

In Table 1 parameters used in computations are presented.

Table 1.

Parameters used in computations.

\begin{tabular}{lll}
\hline $\begin{array}{l}\text { Dimension of side of elementary cell } \\
\text { in direction of } k-\text { axis }\end{array}$ & \\
Dimension of interparticle contact & $a_{k}(\mathrm{~mm})$ & $1 . \times 10^{-4}$ \\
in direction of $k-$ axis & $x_{k}(\mathrm{~mm})$ & $2.5 \times 10^{-6}$ \\
Volumetric factor of share & $\alpha_{V}$ & 1.0 \\
Sur face factor of share & $\alpha_{S}$ & 1.0 \\
Radius of particle & $R(\mathrm{~mm})$ & $0.5 \times 10^{-4}$ \\
Uniaxial compression & $\sigma_{z}(P A)$ & $50.0 \div 300 \times 10^{-6}$ \\
Powder material yield limit & $\tau$ & $285.0 \times 10^{6}$ \\
Modulus of elasticity of bronze & $E$ & $19.62 \times 10^{10}$ \\
\hline
\end{tabular}

Let us present some results of numerical experiments. In Fig. 4, the depen-

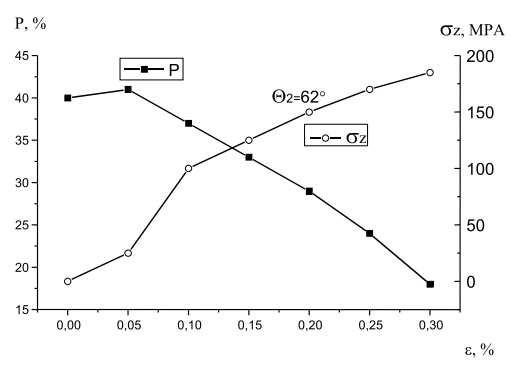

Figure 4. The dependence of the porosity and uniaxial compression on the degree of axial compression deformation. 
dence of the porosity and axial compression on the degree of axial compression deformation is shown. In Fig. 5 the results of investigations of the dependence of the porosity on the magnitude of axial compression deformation for various angles in the elementary cell are given. Fig. 6 illustrates the influence of the degree of axial compression deformation upon the sizes of pores and the specific surface. The analysis of the results also shows that in the plane containing the deformation axis there is a substantial change in the shape of particles and pores, no changes are observed in the plane perpendicular to the axis. The theoretical data are confirmed by results of experimental investigations. The relative deviation of the theoretical results from the practical data does not exceed $10 \%$.

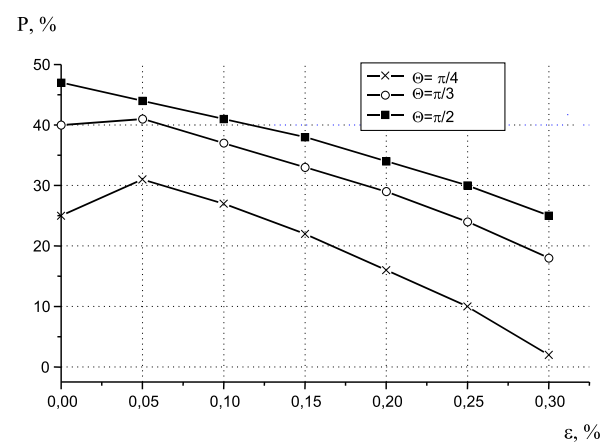

Figure 5. The dependence of the porosity on the degree of axial compression deformation for various corners in the elementary cell.

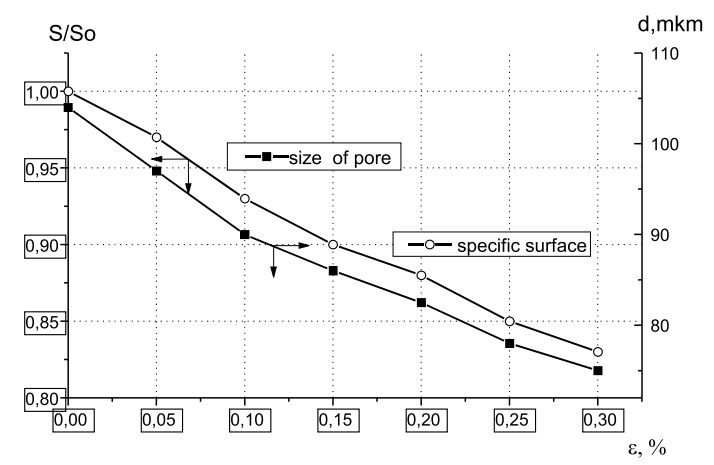

Figure 6. The dependence of the sizes of pores and the specific surface on the degree of axial compression deformation. 


\section{REFERENCES}

[1] A.I. Borisenko and I.E. Taranov. Vector analysis and principles of tensor calculus. Kharkov, 1978. (in Russian)

[2] M.A. Coulomb. Essai sur une application des regles des maximie of minimis a' quelques problemesde statique relative a' l' architecture. Mem. Acad. Roy. Divers Sav., 5(383), 1967.

[3] J.A. Dodds and P.J. Loyd. A model for the void structure in multicomponent sphere packs applied to capillary pressure curves. Powder Techn., 5, 1971/72.

[4] D.C. Drucker and W. Prager. Solid mechanics and plastic analysis of limit design. Quart. Appl. Math., 10(157), 1952.

[5] F.A.L. Dullien. New network permeability model of porous media. AICHE Journ., $\mathbf{2 1}(2), 257-536,1975$.

[6] R.J. Grin. Theory of plasticity of porous bodies. Science, Moscow, 1990.

[7] G.M. Jdanovich. Resistance of powder materials. Minsk, 1999. (in Russian)

[8] V.D. Khliushnikov. Mathematical theory of plasticity. Moscow, 1979. (in Russian)

[9] M. Oyane, S. Shima and Y. Kono. Theory of plasticity for porous metals. Bull.of the ISME, 16(99), 1973.

[10] R.T. Shield. On Coloumb's law of failure in solids. J. Mech. Phys. Solids, 4(10), 1955.

[11] K. Shimamura and K. Suzuki. Model experiment of the deformation behaviour porous sintered materials. J. Jap. Soc. Powder Met., 22(8), 1976.

[12] M.B. Shtern, G.G. Serdiuk, L.A. Maksimenko and etc. Pressing theories of powders. Kiev, 1982.

[13] I.J. Smalley. Variations on the particle parking theme of graton and fraser. Powder Techn., 4, 1970.

[14] W. Szchzepinski and H. Petryk. On the mechanism of deformation of density hardening granular materials. Bull. de L'Acad. Pol. Sci. Ser.sci.techn., 24(3), 411-417, 1978.

[15] P.A. Vitiaz, V.M. Kapcevich and R.A. Kusin. Filter materials. Minsk, 1999. (in Russian)

\section{Plastiškų deformacijų modeliavimas poringose miltelių medžiagose}

G. Zayats, R. Kusin, V. Kapcevich

Šiame darbe aprašomos ir nagrinėjamos plastiškos poringų miltelių medžiagos (PPM) deformacijos, atliekamas skaitinis ju modeliavimas. Šis modelis leidžia prognozuoti PPM technologinių parametrų kitimą plastinių deformacijų savybèse. Poringosios medžiagos vienetinè ląstelè aprašoma aštuoniomis miltelių dalelëmis. Šios vienos medžiagos ląstelès parametrai formuoja poringosios terpès modelị ir apibrěžia jo technologines charakteristikas. İ šį modeli įtraukti PPM savybių neizotropiniai efektai. Skaičiavimai atlikti neortogonalioje koordinačiu sistemoje susietoje su vienetine ląstele. Gauti skaitiniai rezultatai neašinèms itampoms rodo gerą atitikimą eksperimentiniams matavimams. 